Article

\title{
From Words to Action: Incorporation of Sustainability in Architectural Education
}

\author{
Badiossadat Hassanpour *, Resmiye Alpar Atun and Soheil Ghaderi \\ Department of Architecture, Faculty of Architecture, Eastern Mediterranean University, Famagusta, TRNC via \\ 10 Mersin, Turkey; resmiye.alpar@emu.edu.tr.com (R.A.A.); ghaderi.arc@gmail.com (S.G.) \\ * Correspondence: badiossadat.hassan@emu.edu.tr; Tel.: +90-392-630-2224
}

Received: 6 July 2017; Accepted: 30 September 2017; Published: 6 October 2017

\begin{abstract}
Schools of architecture play a major role in motivating and inspiring students to gain competencies in sustainability through pedagogical practices. However, at the operational level, the incorporation of sustainability within architectural programmes needs to be integrated into both the curricula and teaching methods. There are few studies on how architectural programmes' curricula and pedagogical practices can be institutionally articulated, as well as on how the required coherency among components can be empowered operationally. Since the interrelation of the courses form the structure of the curricula and provide certain inputs for the students' knowledge and skill, any operational risk can harm the quality assurance. Therefore, an operational framework aimed for a coordinated incorporation of sustainability in architectural programmes is required. In order to achieve this, scrutinising substantial equivalence programmes could provide constructive outcomes for the improvement of the existing programmes and future experiences for students. In order to determine the articulation of sustainability issues in architectural education, in this research, a recently accredited school in the Eastern Mediterranean region was chosen as a case study. The study includes an analysis of course descriptions, teaching methods, and teacher and student perceptions about the incorporation of sustainability into the courses. Also, jury sessions' evaluation criteria are assessed as a pedagogical tool. Then, the horizontal and vertical articulation of courses within the curricula and their coordination were studied accordingly. The findings reveal that horizontal and vertical relations between different course types that share similar learning objectives are very important. However, this relation and continuum should be perceivable by students, tutors, and the relevant stakeholders; otherwise, any attempt would remain superficial. Accordingly, the association of sustainability with pre-defined evaluation criteria for grading is very important. The methodological tools and lessons from this study can assist young architecture programmes with the incorporation of sustainability into their programme without changing its spirit, through the coordination of courses within curricula and adopted pedagogical tools.
\end{abstract}

Keywords: accreditation; architectural education; assessment tool; sustainability; curriculum

\section{Introduction}

The United Nations Conference on the Human Environment that took place in Stockholm in 1972 introduced sustainability in response to the threat posed to the environment. The concept was further developed in 1992 when it was discussed at the Rio de Janeiro conference. Since then, it has been discussed as part of various priorities in different periods under diverse terminologies and titles [1]. The term 'sustainability' has been broadly used in the field of architecture and urban planning [2]. Hawkes (1996) [3] and Hagan (2001) [4] theorised that a direct relationship between architecture and the environment exists, and the major role played by both factors in providing for basic human needs [5]. From the 1970s until 2000, the focus of local and international movements changed from 
environmental design in 1970 to green design in 1980, to ecological design in 1990, and finally to sustainable design in 2000 . There are subtle differences between these terminologies. The US Green Building Council [6] stated that "green design often implies an interest in design that protects people's health and well-being, while sustainable design also protects the global environment and the world's ecosystems for future generations".

Although there are many approaches in defining sustainability, they have common measures. Gibson (2005) [7] defined sustainability as "a global procedure that attempts to present an enduring future in which environmental, social, and economic features are considered". Yilmaz (2006) [8] describes sustainability as a connective method for nature and humanity in the context of time. The current popular concept of sustainability urges society to be flexible enough to avoid destroying the economic, social, and natural systems that support it [9]. Sustainability in architecture is a subject that does not relate to a specific style of architecture; rather, it is an outcome of activities involved in building and construction that can assist in providing aid to humanity and the environment. Building environment is the main content of human life, and it enables a better quality of life. As a result, sustainability was found to be a goal to achieve by means of different aspects of design [10].

Some of the fundamental principles of good design are achieved by paying attention to factors such as: local climatic conditions, the position and orientation of building structures, topography, local architectural form, the local environment, applying local construction techniques, using local materials, designing windows, shading devices and louvres, recycling, minimising preservation costs by pre-planning, and flexible design from providing possibilities for altered usage in the future [11]. Arguably, the aforementioned topics should be considered as subjects for inclusion into the architectural profession as part of its integrated approach. Architectural education has always demonstrated awareness of its influences on cultural constructs [12-14]; for example, by reflecting changes in the professional landscape.

Therefore, institutions should adopt sustainability as a priority by motivating students to adopt the essentials of sustainable improvement through using appropriate pedagogical techniques, methods and tools, as well as by ensuring sufficient research [15]. Education is of paramount importance [13]; it is the process of facilitating learning and acquisition of knowledge, skills, and academic content, which is taught in a school or in a specific programme. Architects' ability to create or design sustainable buildings is closely related to them obtaining skills, knowledge, and abilities in this subject during the education process [16]. The curriculum at the core of architectural education contains plans, objectives, teaching methods, and content that are used to conduct educational activities and attain certain educational aims.

The curriculum relates knowledge from one lesson to the next across a programme of study, and it integrates knowledge across different classes. An integrated curriculum uses both vertical and horizontal articulations. In a vertical articulation, what is learned in one lesson prepares students for the next lesson. It establishes skills and knowledge that are used in further developments across a whole programme of study. In this way, basic skills and knowledge are both developed and reinforced as other elements are introduced into study. This method of teaching is structured and progressive, and it focusses on building advanced levels of knowledge. Horizontal articulation means that what is studied in one particular course in an institution is in line with other, similar classes, both in terms of course content and evaluation [17]. Creating a single, unified curriculum that avoids clashes between components requires functional interdependence, mutual adaptation, and clarification of interfaces and junctions, which also helps to decrease abortive work. Therefore, curricula need to include a framework to achieve a certain level of educational quality.

Moreover, the whole procedure has to be active rather than passive. This means that the whole education process should provide students with the capability to use their new knowledge in real life [18]. In this way, students would be encouraged to contend with various ways of looking at problems, to think creatively and become more deeply involved in working on issues that are complicated and multifaceted; this activity can take place in both experiential and classroom settings. 
Several important attributes for active education lead to a noticeable changes in student thinking and actions. These attributes include: knowledge, comprehension, application, analysis, synthesis, and evaluation [19]. Knowledge identifies and refers to a category of situations and behaviours that focus on remembering subjects, thoughts, and events such as recognition and recall. Knowledge can be categorised as a variety of accurate and reasonable information that includes both general and abstract information [19]. The application of knowledge enables students to think and act individually when it comes to finding suitable topics. Therefore, students do not need to be told what an appropriate topic is, or how it can be used.

The analysis concentrates on separating the constituent factors of a topic, determining its internal organisation and the interactions between its components. Synthesis focuses on incorporating factors to produce a new pattern that illustrates a creative behaviour. Evaluation is not necessarily representative of the final procedure of cognitive behaviour. Sometimes, evaluation is an introduction to the start of the recognition procedure, because it comprises the characteristics of a communication bridge between emotional behaviours and cognitive behaviours [20].

The three main pillars of sustainability are the environmental, economic, and social aspects. These three pillars need to permeate into the undergraduate curriculum in a homogeneous way that considers the organic relations amongst all of the curriculum components.

Despite the striving of many university leaders, the slow rate of change in universities shows the depth of the challenge [21].

Attaining sustainable competency in architecture students has been tried trough several influential architecture schools' endeavors. As an example, a Philadelphia university in the United States (US) implemented a collaborative curriculum into the architecture programme [22]. Instructors from other disciplines were invited to join at various intervals to provide diverse feedback to architecture students and to draw their attention to universal design principles, energy efficiency, practical issues, and so on.

Ball State University, in Indiana in the US, is another example of a programme that creates situations for several voices in the studio and that also develops interdisciplinary methods between ecologists, sociologists, designers, and so on [23].

The other exploratory study was done by analyzing the curricula of 20 selected influential schools in 11 countries in Far East Asia [14]. However, only a limited number of architecture programmes have attempted to find solutions for mutual goals by establishing a situation in the design studio pedagogy and curriculum in a holistic manner [21].

Accreditations can be an aid to obtain standard quality values and assure the incorporation of sustainability into the curriculum through determined curriculum assessment tools by means of realms and criteria. The most reputable architectural accreditation boards are the NAAB (National Architectural Accreditation Board) and RIBA (Royal Institute of British Architects). They require an architectural programme report based on student performance as one of the main evaluation criteria [24]. NAAB divides student performance criteria into three realms (A, B, and C) with elaboration on each criterion of different realms. The explained criterion details that need to be addressed and incorporated into the syllabus were used as a tool to indicate the sustainability themes in Table 1. As Table 1 indicates in grey colour, students performance criteria elaborates on the theme of sustainability in several places.

It requires knowledge of the principles and concepts of sustainability in creating urban design and architectural projects to be embodied within course contents and objectives, and sustainability must be demonstrated in student studio projects [24].

As Table A1 indicates, in RIBA-defined categories, there are 11 main sections in the General Criteria for Parts I and II; these comprise 33 sub-criteria that address aesthetics and technical, structural, and planning considerations, including cost requirements. Sustainability is considered within these sub-criteria in the relationship between people and buildings, as well as with the environment, and the impact of buildings on the environment. The precepts of sustainable design are also mentioned. 
Table 1. Incorporation of sustainability in NAAB's 'student performance criteria'.

\begin{tabular}{|c|c|c|c|c|c|c|}
\hline \multicolumn{2}{|r|}{ Realm A } & \multicolumn{2}{|r|}{ Realm B } & \multicolumn{3}{|r|}{ Realm C } \\
\hline $\mathrm{A} 1$ & Communication Skills & B1 & Pre-Design & & $\mathrm{C} 1$ & Collaboration \\
\hline A2 & Design Thinking Skills & B2 & Accessibility & & $\mathrm{C} 2$ & Human Behavior \\
\hline $\mathrm{A} 3$ & Visual Communication & B3 & Sustainability & * & $\mathrm{C} 3$ & Client Role in Architecture \\
\hline A4 & Technical Documentation & B4 & Site Design & * & $\mathrm{C} 4$ & Project Management \\
\hline A5 & Investigative Skills & B5 & Life Safety & & C5 & Practice Management \\
\hline A6 & Fundamental Design Skills & B6 & Comprehensive Design & * & C6 & Leadership \\
\hline A7 & Use of Precedents & B7 & Financial Consideration & & $\mathrm{C} 7$ & Legal Responsibilities \\
\hline A8 & Ordering System Skills & B8 & Environmental Systems & * & C8 & Ethics \& Professional Judgement \\
\hline A9 & Historical Traditions \& Global Culture & B9 & Structural Systems & & C9 & Community \& Social Responsibilities \\
\hline A10 & Cultural Diversity & B10 & Building Envelop System & * & & \\
\hline \multirow[t]{2}{*}{ A11 } & Applied Research & B11 & Building Service System & & & \\
\hline & & B12 & Building Material \& Assemblies & * & & \\
\hline
\end{tabular}

Addressing sustainability also involves considering underlying physical problems and technological criteria, which include principles associated with designing optimum audio-visual comfort, thermal comfort, and systems for environmental comfort. These criteria are realised within the relevant precepts of sustainable design, and the ability to integrate these in a design project.

In addition to these factors, the professional criterion in Part III includes an emphasis on environmental sustainability legislation under legal frameworks and process criteria [25].

The terms knowledge, understanding, ability, and skills are used in the general criteria to indicate the nature of achievement required as the student progresses.

Recently, RIBA has been working intensively with the government to create a new policy regarding sustainability development in architecture [25].

It is clear that each of the aforementioned boards has, to varying extents, embraced sustainability; however, all of the aspects are considered only broadly, and they are co-equally dispersed.

Findings from the aforementioned studies acknowledge that there is currently no definite path towards a holistic and integrated sustainability knowledge into the curriculum, and there is no agreed approach for delivering the acquisition of this knowledge to students.

While there is a certain amount of will, many universities, schools and programmes cannot determine ways to incorporate a new pedagogical emphasis into traditional settings; consequently, the orientation towards sustainable design is also affected [21,23,25-29].

Several architecture schools and departments have attempted to discover appropriate ways to improve sustainability integration in architectural education; however, the challenge to change is more intentional than operational, and even then, it is mostly infrequent and uncoordinated [30,31].

This paper aims to provide an insight into an operational framework towards the balanced incorporation of sustainability in architectural programmes. The applied analysis provides a possible operational tool to maintain a standard of education with regard to sustainability issues within architectural programmes. The curriculum of architectural programmes is a vital consideration in order to to support architectural education for further professional experiences.

\section{Method}

In order to assess the level of integration of sustainability programs in an Eastern Mediterranean location, a case study methodology was employed.

Since accreditation is accepted as an assessment tool for achieving a quality review, an aid to obtain standard quality values, and a driving force for further developments and continuous improvement [32], studying the components of accredited architectural programmes provides a reliable source of evaluation in terms of the level of sustainability incorporation.

The architecture programme at Eastern Mediterranean University in North Cyprus was recently (1 January 2016) awarded substantial equivalence by NAAB, and was found to be a valuable case study. In total, 550 students enrolled in the substantially equivalent degree program. This number includes all of the registered students in the program at the end of the 2013-2014 spring semester. 
To comprehend the prevailing situation relating to sustainability incorporation, a multi-layered methodology was deployed. All of the components of the selected case study (an architecture programme at Eastern Mediterranean University) curriculum have been studied in regard to the incorporation of sustainability issues. A required architectural program report (APR) by accreditation boards requires clarification about recent performance relating to student learning, the curricular framework, and student achievements, and is used as a self-study tool for the programme.

All of the details derived from the programme were tabulated and charted, including the used evaluation criteria in jury sessions. The various factors scrutinised included course description, teacher and student opinions about incorporating sustainability within each course, and the prepared architectural programme report (APR) from 2014. Then, the horizontal and vertical articulation and manner of coordination were studied. Finally, the particular features and attributes of the programme were considered, and general recommendations were developed. Below items have been selected as the main components of an applied research methodology.

\subsection{Participants}

The architecture programme at EMU offers a four-year integrated curriculum. The curriculum allows students to enrol in lectures that are complementary to the general education philosophy of the university. The main focus is that the architectural design studio is augmented by professional theory courses and first-year service courses. The interactive studio, as the proper arena for critical thinking, provides a milieu to address the social, technical, and environmental issues surrounding an architectural project, through recreation of, and discussion about, the spatial dimension of the built environment. Undergraduate courses are categorised as: first-year foundation, design, theoretical (area), area elective and university elective (general education). The programme contains a total of 47 courses (158 credits, including summer practices) and syllabuses. The first semester includes 20 credits, the second to sixth semesters each contain 21 credits, the seventh semester comprises 18 credits, and the eigth semester has 15 credits. The full curriculum is shown in Table A2. There are 29 professional studies included within 47 courses. When the distribution of the professional studies that begin in the second year is taken into consideration, it can be seen that there are 13 courses available in the second year, 11 in the third year, and four in the fourth year (including the summer practices, which have no credits). According to their area of interest, students must enroll in five professional elective courses offered by the architecture faculty. University elective courses taken in subsequent years give students the opportunity to select courses according to their areas of interest.

The respondents of this study survey were 293 students and instructors in the department of architecture at EMU. All of the participants in this study were volunteers. Student participants included 162 male and 108 females between the ages of 18 and 23. These 270 volunteer students ( 45 percent of the total student number) were from six design studios in the second, third, and fourth year of their architecture education (referred to as Arch291, Arch292, Arch391, Arch392, Arch491, and Arch492).

To increase the reliability of the results, first-year students were excluded from this part of the survey due to their lack of knowledge and experience in architecture education.

Instructors in the department of architecture who participated in the survey were mainly the coordinators of the design studios and the theoretical courses within the last two years of the research. In total 23 instructors comprising three Prof. Dr, six Assoc. Prof. Dr, and eight Asst. Prof. Dr. and four senior lecturers.

\subsection{Material and Measures}

Student questionnaires developed by the authors were based on indicators of accreditations and comprised four questions. The first three questions were designed based on a Likert scale from one to five. The questions asked respondents to compare the level of sustainability incorporation in design studios, and in elective and theoretical courses. The aim of questions was to reveal the teaching and learning methods used to transmit sustainability issues, and ultimately to determine how much 
sustainability was considered by juries as an evaluation criterion while commenting and grading. The final question in the student questionnaire named all 30 "must" courses where they believed sustainability issues were discussed, and ought to mark the aspect(s) covered.

Course descriptions for all of the "must" courses in the programme and the course matrix in APR (prepared for a second visit by NAAB to EMU's Faculty of Architecture in the 2014-2015 academic year) were reviewed in a comparative study. These results are shown in Table 5, and they were analysed qualitatively.

In the entire architectural education process, each design studio is supposed to deliver special challenges. FARC101 aims to help students learn about formal elements used in design, their characteristics, and the principles that are used in creating design works. Subjects related to human dimension, functional requirements, and form-function relationships are also dealt with.

FARC102 aims to familiarise students with the basic issues of design, and introduce these issues with the help of a small-scaled introductory design project.

ARCH291 expects students to deal with the issues of designing small-scaled complexes, and main include accommodation that serves the human behaviour of a special user group (age, interest, profession, etc.) in a given rural context as the site. ARCH292 aims to develop architectural design skills or students on reasonably complex design in terms of contextual and functional issues in architecture. Accordingly, this course provides an understanding of form, function, and space relations based on projects with fairly complex functions that are in a settled district or neighborhood. The emphasis is on a holistic design approach that is initiated from an architectural scenario and carried through to site, and includes considerations for the environment (design with nature, using topography in design, sun-wind direction, orientation and other climatic factors), special needs in relation to social factors, and appropriate construction techniques, materials, and details.

ARCH 391 aims to develop students' skills in urban design. Students are expected to design a building complex with functional and spatial sophistication, with particular sensitivity to the existing context, social factors, quality, and hierarchy of open and semi-open spaces, landscaping, urban design issues, and accessibility issues.

ARCH392 aims to provide students with the skills of designing buildings with high complexity in functional structural and constructional terms, while responding to an urban condition with peculiar socio-cultural, economic, and historical parameters.

ARCH491 aims for an emphasis on designing buildings with high complexity in regard to appropriate structural systems, and creating rich architectonic qualities. The course introduces an integrated approach to design. The emphasis is put on the creative design of a building and ensemble that accurately situates the project on the site, while providing a unified form that integrates interior and outdoor space, structure, programme, building construction, and bio-climatic concerns within a viable solution.

ARCH492 is the final project, in which students are expected to work from the macro to the micro scale, and has a special emphasis placed upon individual interest areas. Consideration for the holistic nature of the design product, from the abstract initial form to the final concrete design outcome, is expected to develop throughout the semester. Therefore, progress throughout the design process is important. Professional abilities include architectural research, literature survey and time management skills, and almost full attendance at reviews and discussions. Midterm, pre-final, and final juries are also required.

Curriculum, syllabus, and course descriptions are more content-based, whereas teaching methods, teaching tools, pedagogy, and the evaluation system are part of the process of imparting knowledge. To achieve the aims of each studio and to boost the vertical coordination, different jury members from upper and lower educational levels are invited to the midterms and to the final juries. Therefore, the percentages of internal and external jury members are assigned according to tutor-student relationships within each educational semester. Since midterm and final juries are the main measures in evaluating course outcomes, coherencies amongst process, the final product, and applied criteria in juries needs 
to be explored. Hence, it was brought to the research as one of the main measures in evaluating the role of sustainability involvement in each studio.

\subsection{Procedure}

The survey was administered to review and identify the substantive contributions of each course within an assigned semester and within the whole curricula in supporting students' competencies regarding sustainability issues. Peer review provides a valuable opportunity to scrutinise the complicated matrix of horizontally and vertically related courses from an operational perspective. Therefore, studying course descriptions, teacher and student ideas about courses, and prepared APRs could help uncover the hidden truth in thematic studies.

Four measures, including course outline, student opinion, tutor opinion, and the EMU Architectural Program Report (APR) were set as measuring tools in assessing the sustainability involvement of each course. The questionnaire surveys among students and tutors were synchronised, and the results were checked with the course description and covering realms of APR. It should be noted that the proposal of the research and research method submitted to the relevant committee, and the completed evaluations, were based on the ongoing ethic regulations at the time of study. Participation in this study has been voluntary. The candidates for the research had the right not to participate at all. It was based on the understanding that no identifying information through which the sources of original data can be determined would be made available, and strict controls were maintained to safeguard the confidentiality of the information.

\section{Analysis}

As this research aimed to sketch an operational framework towards the converging and coordinated incorporation of sustainability in architectural programmes, the studied components of the selected case study included pedagogical practices in design studios, course descriptions, horizontal and vertical relations among related courses, and student and tutor perceptions.

Table A2 indicates columns including course codes, course title, pre-requisites, the result of the case study survey, and types of sustainability accomplished. Pre-requisite courses are included due to the horizontal and vertical articulation of the curriculum, and basic knowledge gained through this reciprocal relation. Responses towards sustainability in each column are presented in grey colour and marked with $(*)$. Moreover, elaborated types of sustainability in each respective column are based on the case study survey.

These analyses create a holistic image and mapping of the whole curricula and pedagogical practices regarding the sustainability issues. The findings of all of the aforementioned measures were scrutinised and compared, and results are visualised through a series of tables and figures.

\subsection{Student and Tutor perception regarding Sustainability incorporation}

To check the consistency of student perceptions, student understandings of curriculum objectives, and tutor perceptions, ARCH492 students (Graduation Project) were asked to respond to the question 'Mark the courses in the curriculum that cover any of sustainability aspects in the content and course material, and circle the aspect it covers as well'. Among the named 32 core courses and five elective courses choices (three area electives and two university electives) of the curriculum, all of the students picked 20 core courses and five different area elective courses. Table 2 presents the obtained results based on semester, and the sustainability aspects that those courses cover. 
Table 2. Mark the courses in the curriculum that covers any of sustainability aspects in the content and course material, and circle the aspect in covers as well.

\begin{tabular}{|c|c|c|c|c|c|c|c|c|}
\hline & \multicolumn{8}{|c|}{ Academic Semester } \\
\hline & 1 & 2 & 3 & 4 & 5 & 6 & 7 & 8 \\
\hline \multirow{3}{*}{$\begin{array}{l}\text { Course } \\
\text { Name }\end{array}$} & & FARC102 & ARCH291 & $\begin{array}{l}\mathrm{ARCH} 292 \\
\mathrm{ARCH} 244\end{array}$ & $\begin{array}{l}\text { ARCH391 } \\
\text { ARCH311 }\end{array}$ & ARCH392 & ARCH491 & ARCH492 \\
\hline & & $\begin{array}{l}\text { FARC142 } \\
\text { ARCH114 }\end{array}$ & $\begin{array}{l}\text { ARCH213 } \\
\text { ARCH243 }\end{array}$ & $\begin{array}{l}\text { ARCH246 } \\
\text { ARCH252 }\end{array}$ & $\begin{array}{l}\text { ARCH347 } \\
\text { ARCH355 }\end{array}$ & ARCH348 & ARCH449 & ARCH416 \\
\hline & & EN & EN & EN, EC, S & EN, S & $\mathrm{EN}, \mathrm{EC}, \mathrm{S}$ & EN, EC & $\mathrm{EN}, \mathrm{EC}, \mathrm{S}$ \\
\hline
\end{tabular}

Moreover, those students were asked to respond to the (Likert-type scale 5) question 'To what extent do you feel sustainability is incorporated in course content and materials for named course types?' (90 students responded). As Table 3 illustrates, the results are presented based on five credentials of existing architectural program curriculums. In the existing curriculum of the architectural program at EMU, five credentials as $4+4$ are assigned as studio courses, $3+0$ are assigned as theoretical courses, and $2+2$ are assigned as studio-oriented courses and summer practices as an internship. The studio-oriented courses mainly include structure, construction, computer-aided designs, and graphic communication.

As Table 3 presents, design studios mostly incorporate considerations of sustainability issues, while elective courses and internships have minimal incorporation.

Table 3. ARCH492 student responses to the question: 'To what extent do you feel sustainability is incorporated in course content and materials for the named course types?'

\begin{tabular}{cccccc}
\hline Choices & $\begin{array}{c}\text { Design } \\
\text { Studios }\end{array}$ & $\begin{array}{c}\text { Elective } \\
\text { Courses }\end{array}$ & $\begin{array}{c}\text { Theoretical } \\
\text { Courses }\end{array}$ & $\begin{array}{c}\text { Studio Oriented } \\
\text { Course }\end{array}$ & Internship \\
\hline Mean & 4.1 & 2 & 2.5 & 3.4 & 0 \\
\hline \multicolumn{7}{c}{ Standard Variation: 1.07} \\
\hline
\end{tabular}

To figure out how this high level of incorporation in design studios is pedagogically achieved, according to the essence of the self-assessment report of the case study (the prepared APR for accreditations), certain measures have been found as main pedagogical tools in design studios. These include individual critique, lectures, oral discussion, and research projects. Therefore, students were ask to respond to the question, 'To what extent are sustainability aspects in the subject of the named studio activities covered?' As Figure 1 illustrates, in the case of ARCH291, the lectures and oral discussions with students about studio and research projects show similar rates of transferring sustainability knowledge, while there is a notable decrease in regard to critiques given to students. A similar situation occurs in ARCH391 for cases related to research projects, and in ARCH292 for oral discussions. ARCH491 shows a unique pattern of pedagogic tool usage, as it is shown that lectures and individual critiques share a similar range, and oral discussion and research projects almost have similar rates as well. The ARCH392 and ARCH492 cases show an almost similar range. 


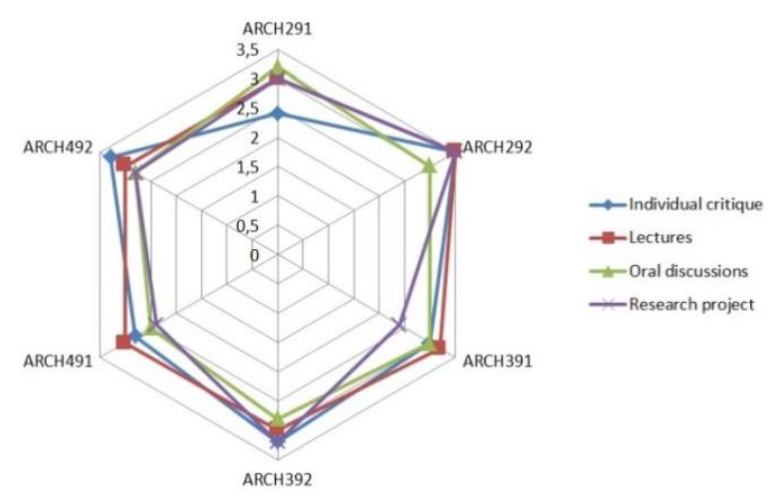

Figure 1. 'To what extent are sustainability aspects in the subject of the named studio activities covered?'

To understand student perceptions regarding the incorporation of sustainability in grades, and to understand the correlations among them, students were asked to respond to the question 'To what extent is sustainability incorporated as a criteria in evaluating your design products in interim submission, midterm, and final jury?'

Figure 2 indicates student opinions regarding sustainability incorporation as criteria in different jury sessions and as criteria of pedagogy in studios. Based on the results presented in Figure 2, a correlational analysis has been run on the data to find out if there is a mutual relationship between any of two sets of data.

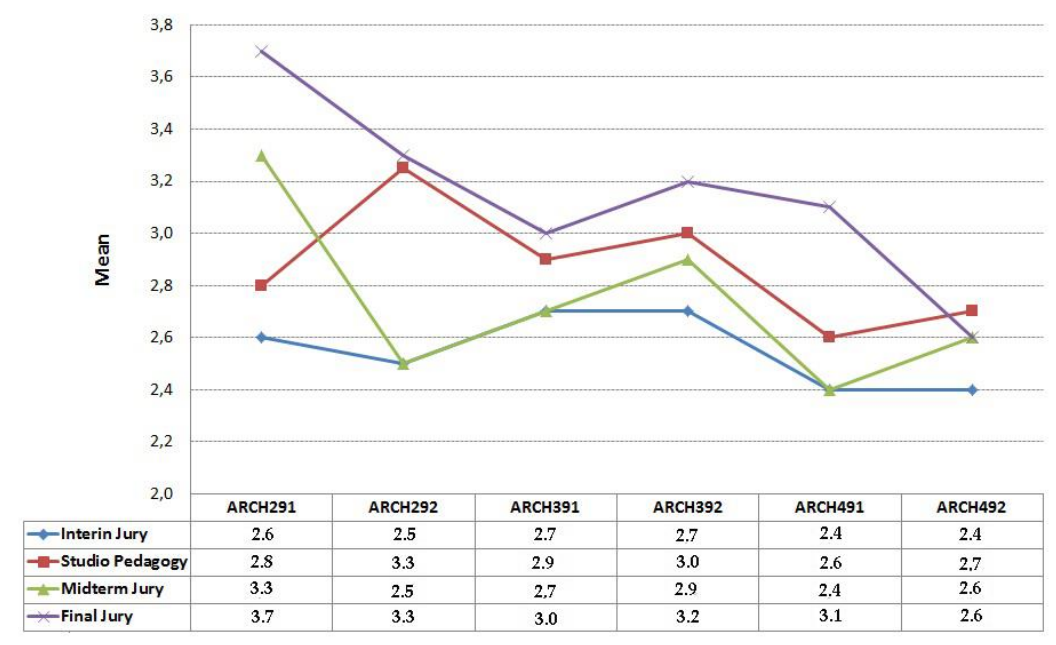

Figure 2. Student responses to the question: 'To what extent is sustainability incorporated as criteria in evaluating your design products in interim submission, midterm, and final jury?'

The absolute value of the correlation coefficient represents the strength of the association between the two sets, and the first calculation expresses the linear dependence between those two variables. As Table 4 reveals, in general usage, the incorporation of sustainability in midterm and final juries are in convenient linear dependence. Juries are special days in architectural education, especially in programmes in which external jury members are involved and student proposals are exposed to the experts for critique. Therefore, a calculated correlation between studio pedagogy and midterm jury from student perspectives is assumable. The midterm jury is their first encounter with externals that aim to interpret and evaluate student outputs based on a multitude of criteria. Midterm juries mainly end up with constructive comments to be used in further steps, which is apparent in the table. These sessions are seen as another pedagogic tool; therefore, the 0.58 and 0.64 correlation coefficient relations are very positive and supportive to the educational aims of the respective studios. 
Table 4. Correlation coefficient regarding the incorporation of sustainability issues between all of the pairs in the database of the EMU case study.

\begin{tabular}{ccccc}
\hline & Interim Jury & Studio Pedagogy & Midterm-Jury & Final-Jury \\
\hline Interim Jury & 1 & 0.42 & $0.58^{*}$ & 0.38 \\
Studio Pedagogy & & 1 & 0.01 & 0.3 \\
Midterm-Jury & & 1 & $0.64^{*}$ \\
Final-Jury & & & 1 \\
\hline
\end{tabular}

* indicates a significant correlation: $\mathrm{P} \leq 0.01$.

To widen the perspective of this research, tutors questionnaires are distributed, which mainly ask students to mark the courses they had provided during the last two semesters, and to mark the sustainability aspect(s) covered. The obtained results revealed that tutors believed sustainability issues are covered in the internship and history and theory courses (ARCH223, ARCH190, ARCH226, ARCH290, and ARCH390) more than the 20 courses selected by students.

As Table 5 indicates, tutors believed that the design studios and studio-oriented courses are comparable in terms of sustainability incorporation.

Table 5. Tutors' responses to the question: 'To what extent do you feel sustainability is incorporated in course content and materials for named course types?'

\begin{tabular}{cccccc}
\hline Choices & $\begin{array}{c}\text { Design } \\
\text { Studios }\end{array}$ & $\begin{array}{c}\text { Elective } \\
\text { Courses }\end{array}$ & $\begin{array}{c}\text { Theoretical } \\
\text { Courses }\end{array}$ & $\begin{array}{c}\text { Studio Oriented } \\
\text { Course }\end{array}$ & Internship \\
\hline Mean & 4.4 & 2.5 & 3.1 & 4.1 & 2 \\
\hline \multicolumn{7}{c}{ Standard Variation: 0.798} \\
\hline
\end{tabular}

In order to elaborate tutor perceptions regarding sustainability integrity levels in different semesters, they were asked to respond the question: 'choose the level of sustainability issues in the course you are involved with in regards to awareness, understanding and competency.' As Figure 3 indicates, student competency in environmental and social aspects of sustainability reaches an understanding level in Semester 4, while competency level is achieved in Semester 7.

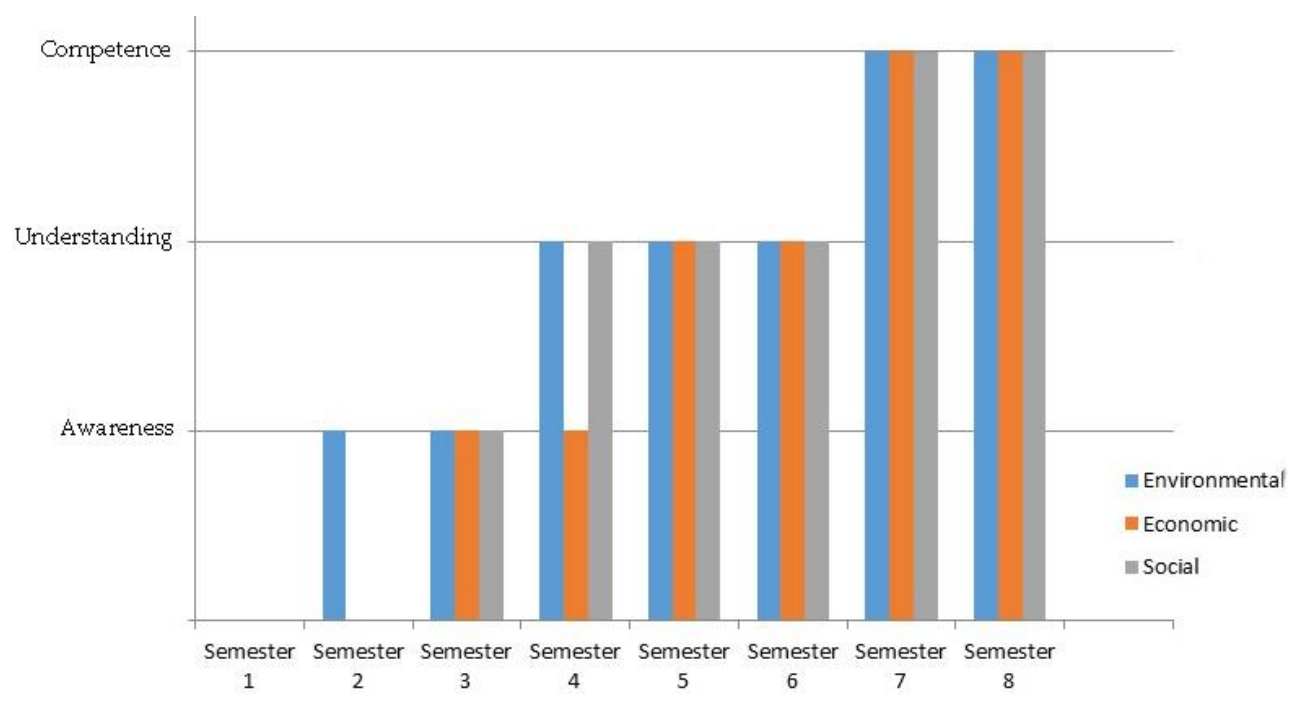

Figure 3. Tutor responses to the question: 'Choose the level of sustainability issues in the course you are involved within in regards to awareness, understanding, and competency.' 


\subsection{Structure of Curricula Focussing on Sustainability}

The focus of this section is elaborating the incorporation of sustainability ideologies into the curriculum of the selected case study, based on course descriptions and the APR's relevant realms and indicators. Table 6 tracks sustainability incorporation in horizontal course relations throughout the whole programme (Spring 2015-2016) at EMU. As shown, studios obtain appropriate input from other courses in the same semester to support the sustainability aspect that is required for the students.

Table 6. Tracking the incorporation of sustainability in horizontal course relations throughout the whole programme (Spring 2015-2016).

\begin{tabular}{|c|c|c|c|c|c|c|}
\hline Semester & \multicolumn{5}{|c|}{ Sustainability in the Courses, Department of Architecture, EMU } & $\begin{array}{c}\text { Covered Sustainability } \\
\text { Aspects }\end{array}$ \\
\hline \multicolumn{3}{|l|}{2} & & & & \\
\hline 3 & \multicolumn{3}{|c|}{ ARCH213 * } & \multicolumn{2}{|l|}{$\begin{array}{c}\text { ARCH243 * } \\
\text { (EN,EC) }\end{array}$} & $\mathrm{EN}, \mathrm{EC}$ \\
\hline \multirow{2}{*}{4} & ARCH292 & \multirow{2}{*}{ (EN,EC) } & ARCH244 * & ARCH246 * & ARCH252 & \multirow{2}{*}{ EN, EC, S } \\
\hline & $(\mathrm{EN}, \mathrm{EC}, \mathrm{S})$ & & (EN) & $(\mathrm{EN}, \mathrm{EC}, \mathrm{S})$ & $(\mathrm{EN}, \mathrm{S})$ & \\
\hline \multirow{3}{*}{5} & \multirow{2}{*}{ ARCH391 * } & \multirow{2}{*}{ ARCH311 } & ARCH347 * & \multirow{2}{*}{ ARCH355 } & & \multirow{3}{*}{ EN, EC, S } \\
\hline & & & (EN,EC) & & & \\
\hline & $(\mathrm{EN}, \mathrm{S})$ & $(\mathrm{EN}, \mathrm{EC}, \mathrm{S})$ & & $(\mathrm{EN})$ & & \\
\hline \multirow{2}{*}{6} & ARCH392 * & ARCH348* & & & & \multirow{2}{*}{ EN, EC, S } \\
\hline & $(\mathrm{EN}, \mathrm{EC}, \mathrm{S})$ & $(\mathrm{EN}, \mathrm{EC}, \mathrm{S})$ & & & & \\
\hline 7 & $\begin{array}{l}\text { ARCH491 * } \\
\text { (EN,EC,S) }\end{array}$ & ARCH449(EC) & & & & EN, EC, S \\
\hline \multirow{2}{*}{8} & ARCH492 * & ARCH416 & & & & \multirow{2}{*}{ EN, EC, S } \\
\hline & (EN,EC) & (EC) & & & & \\
\hline
\end{tabular}

EN: Environmental aspect; EC: Economic Aspect S: Social Aspect. * indicates NAAB realm and indicators of the course presented in the architectural program report (APR); B3, B4, B6, B8, B10, B12.

In order to track the incorporation of sustainability issues in horizontal and vertical course relations throughout the whole programme (Spring 2015-2016), with a focus on prerequisite courses, Figure 4 developed. The objective of this elaboration was to determine the supportive pre-requisite theoretical courses regarding sustainability.

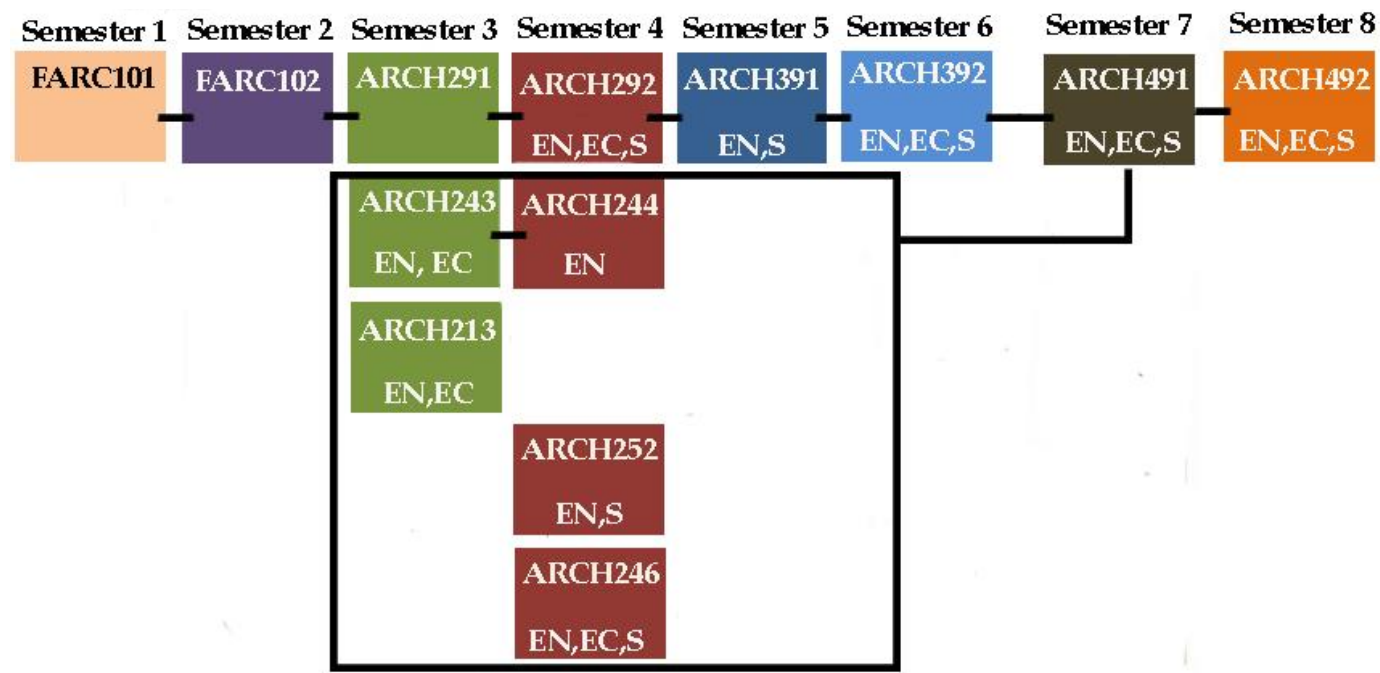

Figure 4. Track of sustainability incorporation in horizontal and vertical course relations throughout the curriculum, with a focus on pre-requisite courses. 
Moreover, it could be perceived that almost all of the sustainability issues are covered by courses in the third semester of architecture education at EMU, to varying extents.

\section{Discussion}

A programme can never address the magnitude or the complexity of the needs without providing a proper level of articulations amongst courses. Especially in the field of architecture, which is known as a multidisciplinary, multi-skilled, multi-dimensional and multimedia practice. Therefore, the expectation from architectural education should be formulated so that they contextualise theory, design studios, and other components of the curricula in a more integrated framework.

Accordingly, in the analysis of the detailed records of each course, the absence of sustainability issues coverage in any of the studied key determinants (student and tutor perceptions, course description, APR) was considered as exemplary of inconsistency and mismatch.

Courses such as ARCH102 and ARCH 142 are exceptional cases in which the course descriptions and EMU APR did not incorporate sustainability very well. According to the findings in the analysis section, based on tutor and student perceptions, sustainability measures are incorporated according to the priority of the semester. At the very beginning of education, in the early semesters of the curricula, responses to sustainability issues are not part of the main aims and objectives of the expected academic semester.

ARCH291 deals with contextual characteristics of sites without any direct response to the main aspects of the sustainability, which is too complex to consider in the third semester of the curricula. As Figure 1 indicates, oral discussions, lectures, and research projects are more engaged with the concerns of the sustainability. However, due to vertical coordination before and after semesters, the range of sustainability incorporation in the individual critique is limited by the priority of the semester.

The result indicated in Table 2 reveal inconsistency and mismatches between the two main actors' perceptions (students and tutors). Courses that exemplify this inconsistency include ARCH223, ARCH190, ARCH226, and ARCH290. The salient majority of students (255 students out of 270) believed that they did not cover sustainability issues in the named courses, while the tutor(s) acknowledged that at least one sustainability aspect could be incorporated.

According to the system of summer practice (internships) at the school, only ARCH190 is under the supervision of tutors, which includes conducting a site survey and site visit. On the other hand, $\mathrm{ARCH} 290$ and $\mathrm{ARCH} 390$ are expected to be conducted at construction site and architectural firms or offices.

Juries have been studied as one of the pedagogical tools in design studios; this has been accompanied by direct observations throughout the whole academic year of study. It is revealed that all of the jury members comment upon and follow students' general and detailed architectural decisions in terms of sustainability at EMU. This tracking by jury members takes place according to students' expected achievement level, beginning with awareness in the early semesters through to competence level at the point of graduation.

Conversely, it has been revealed that jury members rarely comment on economic sustainability before the last two semesters.

As Figure 5 indicates, awareness of sustainability issues is first addressed in the second semester of the first year, with further levels of understanding being developed during second-year semesters (the biggest bars show the maximum level of integration). Subsequently, although integrity levels seem to decrease, the application of learned issues will reach a peak, which could be classed as being competent.

In order to explore the operational sustainability incorporation of the curriculum in regard to pedagogical expectations, student perceptions and curriculum references to aspects of sustainability are compared. As Figure 4 illustrates, in Semesters 4, 6, and 8, the exact expectancy of the curriculum was met, according to student responses. However, still, economic concerns of sustainability were met 
in Semester 7. Moreover, student responses showed that the environmental aspect of sustainability was met, which is beyond the expectation and aim of the curriculum.

\begin{tabular}{|c|c|c|c|}
\hline $\begin{array}{c}\text { Aspects of } \\
\text { sustainability }\end{array}$ & Environmental & Economic & Social \\
\hline Semester 1 & & & \\
\hline Semester 2 & ) & & \\
\hline Semester 3 & (1) & & C \\
\hline Semester 4 & 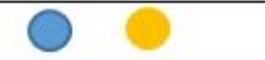 & P & 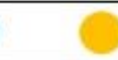 \\
\hline Semester 5 & (1) & & 0 \\
\hline Semester 6 & 0 & & 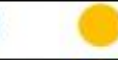 \\
\hline Semester 7 & 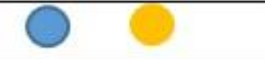 & כ & C \\
\hline Semester 7 & (1) & 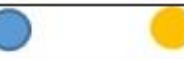 & $C$ \\
\hline
\end{tabular}

Figure 5. Comparative study on student perceptions and curriculum response regarding sustainability incorporation.

General findings reveal that there is considerable interest about sustainability among students and tutors, and they are highly concerned about sustainability issues. The results shared in the findings section demonstrate these aspects to varying extents, and are in organic relations.

\section{Conclusive Remarks}

An integrated curriculum uses articulation and sequencing to reach coherent alignment and a smooth transition of knowledge. Disharmonic approaches and proposals that are not institutionally, educationally, culturally, and technologically coherent within a curriculum would result in anomalies. Therefore, the contingency of integrating sustainability issues into the programme of architecture supports further progress without superimposition.

The following lessons are based on the results from the EMU case; these could be used by other interested architecture schools that share the same concerns as EMU and may be seeking ways to improve their own programmes. The incorporation of any subject into architectural education needs an integrative approach and cohesive actions. Therefore, the integration of sustainability issues in the architecture curriculum would not be achieved by giving an independent and disjointed role to design studios. The substantial role played by design courses in the acquisition of knowledge and skills cannot be underestimated. However, treating design studio courses as a place to compensate for deficiencies in learning outcomes is controversial, and goes against curriculum genesis. Horizontal and vertical relations between different course types that share similar learning objectives are very important.

This relation and continuum should be perceivable by students, tutors, and the relevant stakeholders; otherwise, any attempt at relations would remain superficial and fruitless. Theoretical and studio-oriented courses should have more sustainability content incorporated within them; these should include cultural, economic, social, and environmental issues.

Incorporating sustainability issues in architectural education could be more simply achieved during the final semesters of education; however, this research found it more efficient to introduce these issues to students from the first year. Certainly, the initial level of integration would be relatively low. It could commence with awareness in the first year (second semester, which was found to be positive in the case study), progress towards understanding in the subsequent two or three semesters, and 
develop into competence in the final semesters. In other words, during the early years of architectural education, the rate of discussions, research projects, and studies can be increased, while requirements and expectations from students are restricted to the main goals and objectives of the course. However, closer to graduation this rate can be inverted (Figure 6).

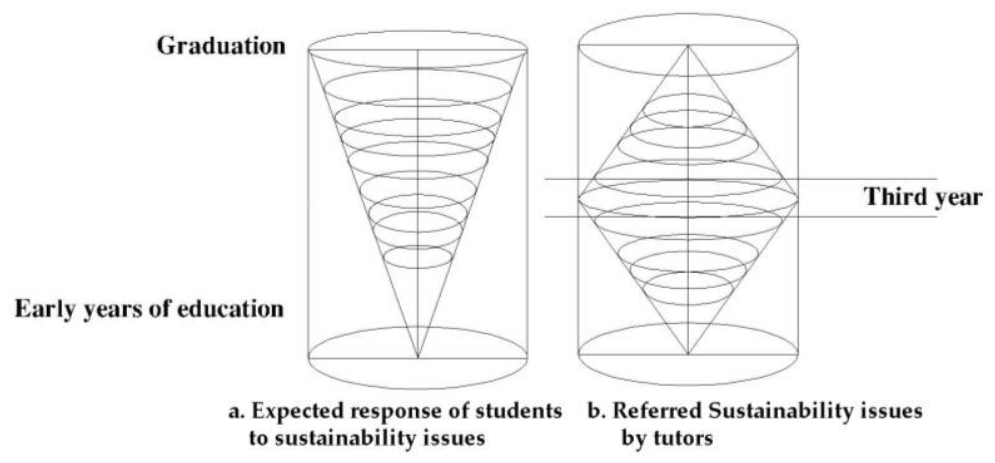

Figure 6. Referred sustainability by tutors and the expected response of students in four-year architectural education.

Moreover, the alignment of sustainability with pre-defined evaluation criteria-particularly in jury sessions-are very important for grading days. External/guest jury members should be given a prior introduction regarding students' sustainability awareness, and majority and minority areas of focus should be set for considering specific aspects (e.g., social/economic/environmental) with regard to grading criteria.

Conversely, although core courses are the main feeding source for any educational programme, elective courses could provide considerable support to students to prepare them for future career and professional life. Therefore, it would be more beneficial to offer a wider range of elective courses, such as theoretical, technological, and studio-oriented courses that follow and support dependent points of the programme and curriculum.

Summer practice courses are very effective in supporting architectural programmes, and they should include more sustainability literacy training content to increase awareness about various aspects of sustainability. There should be a well-defined expectation from students in terms of sustainability considerations, as well as their analysis and implementation within their education process.

\section{Conclusions}

The challenge of sustainable design education lies in recognising the need for change and applying it operationally. Indeed, of all the total number of active architecture departments, only limited numbers of architectural programmes are keen-and also ready-to be reviewed and evaluated in all of the significant aspects that provide an appropriate standard of education with regard to sustainability issues.

The curriculum, the background of educators themselves, the integration of sustainability issues in teaching, and the relations between horizontal and vertical courses throughout the whole programme are critical criteria with regard to quality assurance, and they need to be scrutinised.

Based on the entire study and the obtained results, it can be concluded that the primary aim of international architectural bodies such as RIBA in the UK and NAAB in the US is to ensure that architects are appropriately qualified and competent in their profession. Therefore, it is appropriate to impose certain criteria to review and update the quality of the architectural curriculum to meet the minimum standards of accreditation requirements. This study proposes a methodological tool that will help to assess architecture curricula in accordance with sustainability issues for fulfilling optimum quality reviews during the process of accreditation. 
As a next step, a study will track graduate perspectives and perceptions in order to evaluate the effectiveness of a sustainable architectural education approach. This will be implemented in a selected case study that will review skills and performance in relation to sustainability during practice.

Author Contributions: The authors contributed equally to the development of the research methods, literature review, analyses and evaluation of data, as well as the writing of this article.

Conflicts of Interest: The authors declare no conflict of interest.

\section{Appendix}

Table A1. General Criteria in RIBA Parts I and II [33].

\begin{tabular}{|c|c|c|c|}
\hline Section & Section Description & Numbered subsections & \\
\hline \multirow{3}{*}{ GC1 } & \multirow{3}{*}{$\begin{array}{l}\text { Ability to create architectural designs that } \\
\text { satisfy both aesthetic and technical } \\
\text { requirement. }\end{array}$} & $\begin{array}{l}\text { 1. Prepare and present building design projects of diverse scale and } \\
\text { complexity and type in variety of contexts, using a range of media, and } \\
\text { in response to a brief. }\end{array}$ & \\
\hline & & $\begin{array}{l}\text { 2. Understand the constructional and structural systems, the } \\
\text { environmental strategies and the regulatory requirements that apply to } \\
\text { the design and construction of a comprehensive design project. }\end{array}$ & * \\
\hline & & $\begin{array}{l}\text { 3. Develop a conceptual and critical approach to architectural design } \\
\text { that integrates and satisfies the aesthetic aspects of a building and the } \\
\text { technical requirements of its construction and the needs of the user }\end{array}$ & \\
\hline \multirow{3}{*}{ GC2 } & \multirow{3}{*}{$\begin{array}{l}\text { Adequate knowledge of the history and } \\
\text { theories of architecture and the related arts, } \\
\text { technologies and human science. }\end{array}$} & $\begin{array}{l}\text { 1.The cultural and social and intellectual histories, theories and } \\
\text { technologies that influence the design of buildings }\end{array}$ & * \\
\hline & & $\begin{array}{l}\text { 2. The influence of history and theory on the spatial, social, and } \\
\text { technological aspects of architecture. }\end{array}$ & \\
\hline & & $\begin{array}{l}\text { 3. The application of appropriate theoretical concepts to studio design } \\
\text { projects, demonstrating a reflective and critical approach. }\end{array}$ & \\
\hline \multirow{3}{*}{ GC3 } & \multirow{3}{*}{$\begin{array}{l}\text { Knowledge of fine arts as an influence on } \\
\text { the quality of architectural design }\end{array}$} & $\begin{array}{l}\text { 1. How the theories, practices and technologies of the arts influence } \\
\text { architectural design }\end{array}$ & \\
\hline & & $\begin{array}{l}\text { 2. The creative application of the fine arts and their relevance and } \\
\text { impact on architecture }\end{array}$ & \\
\hline & & $\begin{array}{l}\text { 3. The creative application of such work to studio design projects, in } \\
\text { terms of their conceptualization and representation. }\end{array}$ & \\
\hline \multirow{3}{*}{ GC4 } & \multirow{3}{*}{$\begin{array}{l}\text { Adequate knowledge of urban design, } \\
\text { planning and the skills involved in the } \\
\text { planning process }\end{array}$} & 1. Theories of urban design and the planning of communities & \\
\hline & & $\begin{array}{l}\text { 2. The influence of the design and development of cities, past and } \\
\text { present on the contemporary built environment }\end{array}$ & \\
\hline & & $\begin{array}{l}\text { 3. Current planning policy and development control legislation, } \\
\text { including social, environmental and economic aspects, and the } \\
\text { relevance of these to design development. }\end{array}$ & * \\
\hline \multirow{3}{*}{ GC5 } & \multirow{3}{*}{$\begin{array}{l}\text { Understanding of the relationship between } \\
\text { people and buildings, and between } \\
\text { buildings and their environment, and the } \\
\text { need to relate buildings and the spaces } \\
\text { between them to human needs and scale. }\end{array}$} & 1.The needs and aspiration of building users & \\
\hline & & $\begin{array}{l}\text { 2. The impact of buildings on the environment and the precepts of } \\
\text { sustainable design }\end{array}$ & * \\
\hline & & 3. the way in which buildings fit into their local context & \\
\hline \multirow{3}{*}{ GC6 } & \multirow{3}{*}{$\begin{array}{l}\text { Understanding of the profession of } \\
\text { architecture and the role of architect in } \\
\text { society, in particular in preparing briefs that } \\
\text { take account of social factors }\end{array}$} & $\begin{array}{l}\text { 1. The nature of professionalism and duties and responsibilities of } \\
\text { architects to clients, building users, constructors, co-professionals and } \\
\text { the wider society. }\end{array}$ & \\
\hline & & $\begin{array}{l}\text { 2. The role of the architect within the design team and construction } \\
\text { industry }\end{array}$ & \\
\hline & & $\begin{array}{l}\text { 3. The potential impact of building projects on existing and proposed } \\
\text { communities }\end{array}$ & * \\
\hline
\end{tabular}


Table A1. Cont.

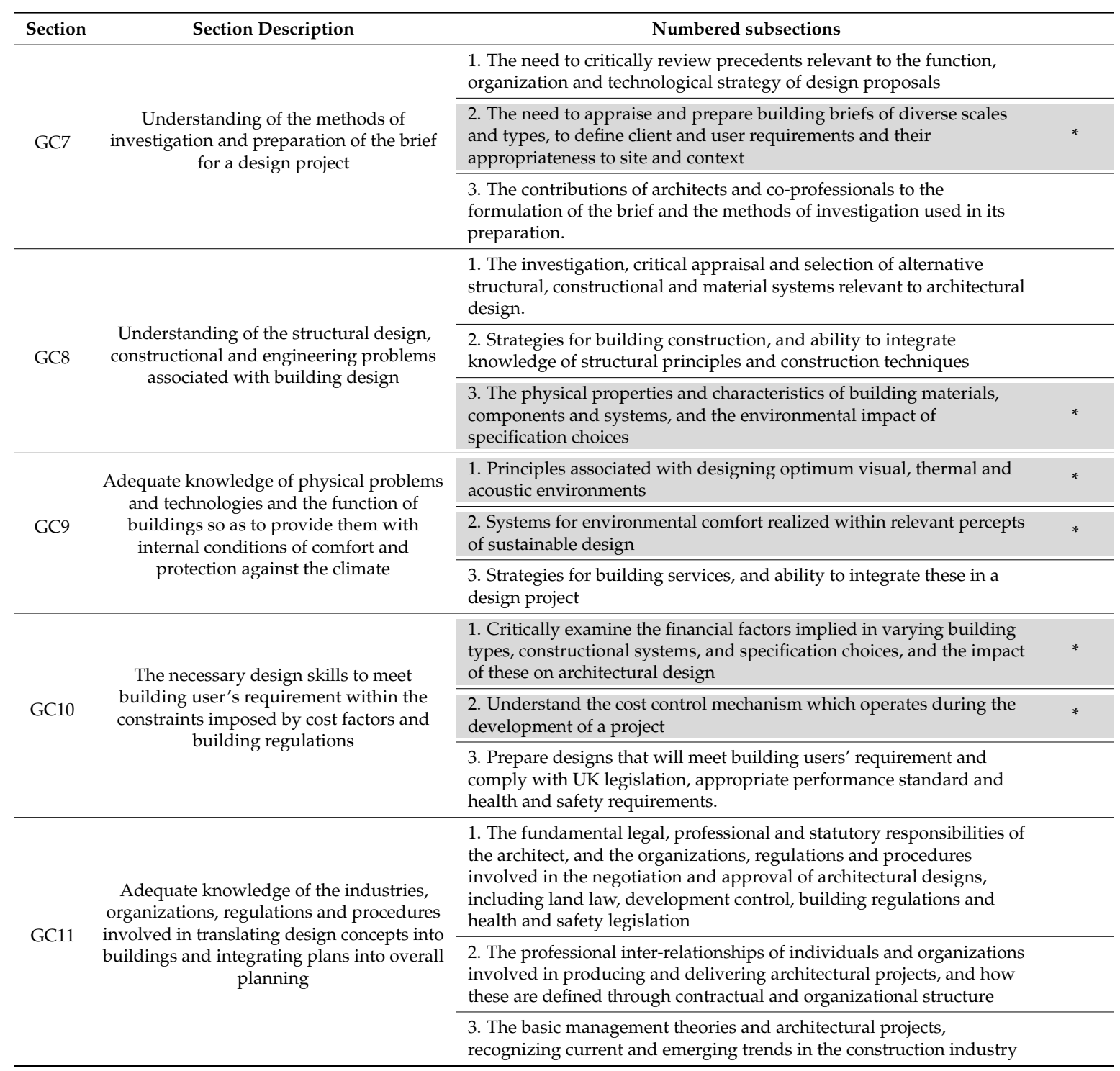


Table A2. Incorporation of sustainability within the EMU architectural programme.

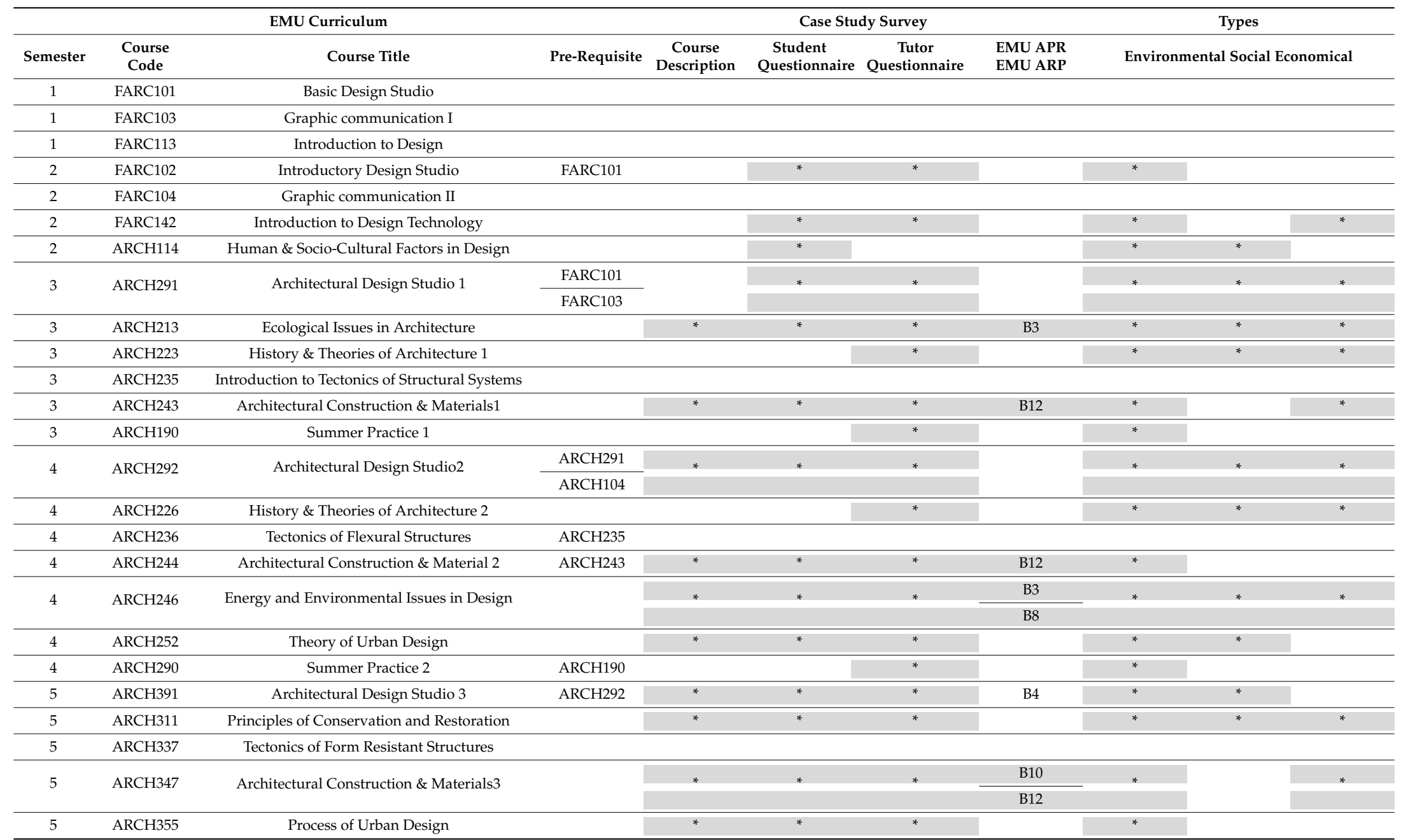


Table A2. Cont.

\begin{tabular}{|c|c|c|c|c|c|c|c|c|c|c|}
\hline \multicolumn{4}{|c|}{ EMU Curriculum } & \multicolumn{4}{|c|}{ Case Study Survey } & \multicolumn{3}{|c|}{ Types } \\
\hline Semester & $\begin{array}{l}\text { Course } \\
\text { Code }\end{array}$ & Course Title & Pre-Requisite & $\begin{array}{c}\text { Course } \\
\text { Description }\end{array}$ & $\begin{array}{c}\text { Student } \\
\text { Questionnaire }\end{array}$ & $\begin{array}{c}\text { Tutor } \\
\text { Questionnaire }\end{array}$ & $\begin{array}{l}\text { EMU APR } \\
\text { EMU ARP }\end{array}$ & Env & Soc & ical \\
\hline 6 & ARCH392 & Architectural Design Studio 4 & ARCH391 & * & * & * & B6 & * & * & * \\
\hline 6 & ARCH348 & $\begin{array}{l}\text { Building and Environmental System in } \\
\text { Architecture }\end{array}$ & & * & * & * & B8 & * & * & * \\
\hline 6 & ARCH390 & Summer Practice 3 & ARCH190 & & & & & & & \\
\hline \multirow{11}{*}{7} & \multirow{11}{*}{ ARCH491 } & \multirow{11}{*}{ Architectural Design Studio 5} & ARCH392 & & & & & & & \\
\hline & & & FARC111 & 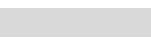 & t & & & & & \\
\hline & & & ARCH142 & 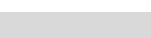 & & & & & & \\
\hline & & & ARCH114 & 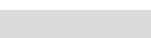 & 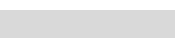 & & 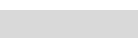 & & & \\
\hline & & & ARCH213 & & & & B & & & \\
\hline & & & ARCH281 & & & & & & & \\
\hline & & & ARCH226 & 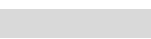 & & & & & & \\
\hline & & & ARCH236 & 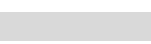 & 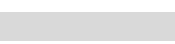 & 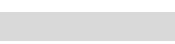 & & & & \\
\hline & & & ARCH244 & 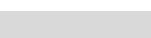 & & & & & & \\
\hline & & & ARCH246 & & & & & & & \\
\hline & & & ARCH252 & & & & & & & \\
\hline 7 & ARCH449 & Economic and Managerial Issues in Architecture & & * & * & * & & & & * \\
\hline 8 & ARCH492 & Architectural Design Studio 6 & ARCH491 & * & * & * & B6 & * & * & * \\
\hline 8 & ARCH416 & Professional Issues in Architecture & & * & * & * & & & & * \\
\hline
\end{tabular}

Note: * sustainability aspects are covered. 


\section{References}

1. UN. The United Nations Programme of Action from Rio: Agenda 21. 1992. Available online: http://www. un.org (accessed on 10 June 2006).

2. Wheeler, S.M.; Beatley, T. The Sustainable Urban Development Reader; Routledge: London, UK, 2004.

3. Hawkes, D. The Environmental Tradition: Studies in the Architecture of Environment; E \& FN Spon: London, UK, 1996.

4. Hagan, S. Taking Shape: A New Contract between Architecture and Nature; Architectural Press: Oxford, UK, 2001.

5. Uzunoglu, S.S.; Uzunoglu, K. The application of formal perception of gestalt in architectural education. Procedia Soc. Behav. Sci. 2011, 28, 993-1003. [CrossRef]

6. European Parliament. Directive 2010/31/EU of the European Parliament and of the Council of 19 May 2010 on the Energy Performance of Buildings. Off. J. Eur. Union 2010, 153, 13-35.

7. Gibson, B.R. Sustainability Assessment: Criteria and Process; Routledge: London, UK, 2005.

8. Yilmaz, M. Sustainable Design in Architecture. In Proceedings of the DS 36: DESIGN 2006, the 9th International Design Conference, Dubrovnik, Croatia, 15-18 May 2006; pp. 1443-1450.

9. Colantonio, A.; Dixon, T.; Ganser, R.; Carpenter, J.; Ngombe, A. Measuring Socially Sustainable Urban Regeneration in Europe; Oxford Institute for Sustainable Development: Oxford, UK, 2009.

10. Bromberek, Z. A conceptual framework for sustainable urbanization in future china. Int. J. Arch. Res. 2009, 3, 186-196.

11. Williamson, T.; Radford, A.; Bennetts, H. Understandings Sustainable Architecture; Spon Press: London, UK, 2003.

12. Wiek, A.; Withycomb, L.; Redman, C.L. Key competencies in sustainability: A reference framework for academic program development. Sustain. Sci J. 2001, 6, 203-218. [CrossRef]

13. Hidalgo, L.; Fuentes, J.M.A. The development of basic competencies for sustainability in higher education. US-China Educ. Rev. 2013, 3, 447-458.

14. Álvarez, S.P.; Lee, K.; Park, K.; Rieh, S. Comparative Study on Sustainability in Architectural Education in Asia-With a Focus on Professional Degree Curricula. J. Sustain. 2016, 8, 290. [CrossRef]

15. Altomonte, S. Handle with care: The challenges of sustainability and the agenda of architectural education. Mimar. J. 2001, 41, 52-60.

16. Yüksek, İ. The Evaluation of Architectural Education in the Scope of Sustainable Architecture. Procedia-Soc. Behav. Sci. 2013, 89, 496-508. [CrossRef]

17. Resnick, L.B.; Rothman, R.; Slattery, J.B.; Vranek, J.L. Benchmarking and alignment of standards and testing. Educ. Assess. 2003, 9, 1-27. [CrossRef]

18. Ellis, G.; Weekes, T. Making sustainability 'real': using group-enquiry to promote education for sustainable development. Environ. Educ. Res. 2008, 14, 482-500. [CrossRef]

19. Fien, J. Advancing sustainability in higher education: Issues and opportunities for research. Int. J. Sustain. High. Educ. 2002, 3, 243-253. [CrossRef]

20. Ismail, M.A.; Keumala, N.; Dabdoob, R.M. Review on integrating sustainability knowledge into architectural education: Practice in the UK and the USA. J. Clean. Prod. 2015. [CrossRef]

21. Fleming, R. Survivor studio @ Philadelphia University: Promoting sustainability in the design studio through collaborative game playing. Int. J. Sustain. High. Educ. 2002, 3, 146-154. [CrossRef]

22. Boyer, E.L.; Mitgang, L.D. Building Community: A New Future for Architectural Education and Practice; Carnegie Foundation for the Advancement of Teaching: Princeton, NJ, USA, 1996.

23. Fowles, B.; Corcoran, M.; Erdel-Jan, L.; Iball, H.; Roaf, S.; Stevenson, F. Report of the Sustainability Special Interest Group (Architectural Education); Centre For Education In The Built Environment: London, UK, 2003.

24. NAAB. 2012. Available online: http://www.naab.org/accreditation/2012_Procedures (accessed on 18 March 2016).

25. RIBA. 2002. Available online: https:/ / www.architecture.com (accessed on 18 March 2016).

26. Wright, J. Introducing sustainability into the architecture curriculum in the United States. Int. J. Sustain. High. Educ. 2003, 4, 100-105. [CrossRef]

27. Abdul-Wahab, S.A. The need for inclusion of environmental education in undergraduate engineering curricula. Int. J. Sustain. High. Educ. 2003, 4, 126-137. [CrossRef] 
28. Elliot, J. Teaching Sustainability to Tomorrow's Interior Designers. Available online: http://www. metropolismag.com/html/sustainable/case/tomorrowsinteriordesigners.html (accessed on 22 May 2006).

29. Ramirez, M. Sustainability in the education of industrial designers: The case for Australia. Int. J. Sustain. High. Educ. 2006, 7, 189-202. [CrossRef]

30. Rider, R.T. Exploring the Integration of Sustainability and Green Building Themes within Formal Architectural Education. Ph.D. Thesis, North Carolina State University, Raleigh, NC, USA, 2010.

31. Rieh, S.; Lee, B.; Oh, J.; Schuetze, T.; Álvarez, S.; Lee, K.; Park, J. Integration of Sustainability into Architectural Education at Accredited Korean Universities. Sustainability 2017, 9, 1121. [CrossRef]

32. Altomonte, S. Environmental education for sustainable architecture. Rev. Eur. Stud. 2009, 1, 12-19. [CrossRef]

33. RIBA Plan of Work. 2007. Available online: http://www.designingbuildings.co.uk/wiki/RIBA (accessed on 18 March 2016).

(C) 2017 by the authors. Licensee MDPI, Basel, Switzerland. This article is an open access article distributed under the terms and conditions of the Creative Commons Attribution (CC BY) license (http://creativecommons.org/licenses/by/4.0/). 